\title{
Reliability and construct validity testing of a questionnaire to assess nomophobia (QANP)
}

\section{Fiabilidad y validez del cuestionario para evaluar la nomofobia (QANP)}

\author{
Ramón Ferri-García1; María Angustias Olivencia-Carrión², María del Mar Rueda'; Manuel Gabriel \\ Jiménez-Torres ${ }^{2}$; Francisca López-Torrecillas ${ }^{2}$ \\ ${ }^{1}$ Department of Statistics and Operations Research and IEMath-GR, University of Granada, Spain. \\ ${ }^{2}$ Department of Personality, Evaluation and Psychological Treatment, University of Granada. Spain.
}

\begin{abstract}
Background: The real meaning of the term nomophobia remains somewhat obscure in studies assessing this disorder. There is an increasing interest in further exploring nomophobia: however, currently available measuring tools appear to only address mobile phone abuse and/or addiction. The objective of this study was to create a Spanish-language instrument to measure nomophobia.

Methods: We developed an 11-item scale that we administered to 968 participants drawn from the population of Granada (Spain). We first performed an Exploratory Factor Analysis. After assessing the nomological validity of the scale, we conducted a Confirmatory Factor Analysis.

Results: The Exploratory Factor Analysis revealed a three-factor structure. Factor 1 (Mobile Phone Abuse) comprised five items that described $19 \%$ of the variance; Factor 2 (Loss of Control) comprised three items that explained $12 \%$ of the variance; and Factor 3 (Negative Consequences) comprised three items that explained $10 \%$ of the variance. Cronbach's Alpha reliability coefficient was 0.80 .

Limitations: Nomophobia is a modern disorder that has yet to be classified as a disease. Self-report measures are affected by biased replies, and therefore the presence of confounders may be a potential issue.

Conclusion: This scale is reliable and valid. It provides future researchers with the means to measure nomophobia in the Spanish population.
\end{abstract}

Keywords: Reliability, Construct Validity, Nomophobia.

\section{Resumen}

Antecedentes: El verdadero significado de la nomofobia parece estar oculto en los estudios que evalúan este trastorno. Existe un creciente interés en profundizar en el estudio de la nomofobia, sin embargo, las herramientas de medición disponibles desarrolladas hasta ahora parecen centrarse solo en el abuso y / o adicción a los teléfonos móviles. Por ello, el objetivo de este estudio objetivo proponer y validar un instrumento de medición de la nomofobia para la población española.

Método: Desarrollamos una escala con 11 ítems que fue administrada a 968 participantes de la población de Granada (España). En primer lugar se realizó un análisis factorial exploratorio y posteriormente se realizó un análisis factorial confirmatorio.

Resultados: El análisis factorial exploratorio reveló una estructura de tres factores. El factor 1 (abuso de teléfonos móviles) está compuesto por cinco ítems y explica un 19\% de la varianza; Factor 2 (Pérdida de control) incluye tres ítems y explica el $12 \%$ de la varianza y Factor 3 (Consecuencias negativas) contiene tres ítems y explica el $10 \%$ de la varianza. El valor del coeficiente de fiabilidad Alpha de Cronbach fue 0.80 .

Limitaciones: La nomofobia es un trastorno moderno que aún no se ha clasificado como patología, las medidas de autoinforme presentas respuestas sesgadas por lo que podemos encontrar algún error o sesgo.

Conclusión: QANP es una escala fiable y válida y proporciona a los investigadores una forma de medir la nomofobia para futuros estudios en la población española.

Palabras clave: Fiabilidad, validez de constructo, nomofobia.

Please cite this article as: Ferri-García, R., Olivencia-Carrión, M. A., Rueda, M. M., Jiménez-Torres, M. G. y López-Torrecillas, F. (2019). Reliability and construct validity testing of a questionnaire to assess nomophobia (QANP). Escritos de Psicología, $12,43-56$

Corresponding author: Francisca López - Torrecillas. Department of Personality, Evaluation and Psychological Treatment, University of Granada. Facultad de Psicología. Campus Universitario de Cartuja 18071 GRANADA, España. E-mail: fcalopez@ ugr.es. E-mail of coauthor Ramón Ferri-García: rferri@ugr.es. E-mail of coauthor María Angustias Olivencia-Carrión: maolivencia@ugr.es. E-mail of coauthor María del Mar Rueda: mrueda@ugr.es. E-mail of coauthor Manuel Gabriel Jiménez-Torres: mjitor@ugr.es. 


\section{Introduction}

The term nomophobia refers to a set of behaviours or symptoms linked to a mobile phone (MP) use. It is the fear of not being able to use the MP or being left without coverage (Bragazzi \& Del Puente, 2014; King et al., 2014). Nomophobia defines the fear of being out of MP contact and is considered a modern phobia. It is the result of an interaction between people and information/communication mobile technologies (Nagpal \& Kaur, 2016). Nomophobia alludes feelings of non-conformity, anxiety, nervousness, or distress because of not being in proximity with the MP (Asensio-Chico et al., 2018; King et al., 2014; Kuss \& Griffiths, 2016) define it as a modern age disorder, and only recently it has been described as a discomfort or anxiety caused by the unavailability of a MP. People affected with nomophobia, or nomophobics, have an irrational fear of being without MP contact or of not being able to use it and try to eliminate any possibilities of this happening. When they are unable to use their MP, they develop intense anxiety, depression, nervousness, and stress (Gao et al., 2018; Szyjkowska et al., 2014; Thomée et al., 2011). Some studies have shown a relationship between MP abuse or nomophobia and common health problems (Movvahedi et al., 2014; Stothart et al., 2015), such as headaches, difficulties to concentrate, memory or hearing loss, and fatigue. Furthermore, nomophobics can also develop physical and psychological problems, e.g., rigidity, muscle pain, ocular affections (Aggarwal, 2013), auditory illusions (pseudo-sensation that the MP is ringing) or tactile illusions (pseudo-sensation that the MP is vibrating) (Lin et al., 2013; Verma et al., 2014), as well as pain and weakness of thumbs and wrists (Ali et al., 2014). Overall, nomophobia has been described as a MP dependence (Dixit et al., 2010) or addiction to MPs (Forgays et al., 2014). Although there are some arguments against MP addiction, the term nomophobia refers to MP addiction or dependence. There is some disagreement on whether problematic use of a mobile/nomophobia can be considered a behavioural addiction (Billieux et al., 2010; Chóliz, et al., 2010; De-Sola et al., 2016; Foerster et al., 2015; Pedrero-Pérez et al., 2012). In previous decades, behavioural addictions were included in the Impulse-Control Disorders section of the Diagnostic and Statistical Manual of Mental Disorders [DSM, (APA, 2002)] from which only pathological gambling was considered an independent diagnostic category and the rest were found in the chapter "Unspecified Impulse-Control Disorders". The creation of the category "Substance-Related and Addictive Disorders" was suggested in the [DSM (APA, 2013)], although only pathological gambling was finally included, not the other suggested substance-unrelated or behavioural addictions. Thus, there are no specific agreed diagnostic criteria for this type of additions, neither in the [DSM (APA, 2013)]. The abusive use of modern technologies is a real problem seriously affecting people who suffer it (Sánchez-Carbonell et al., 2004), thus, currently, there is an increase in the number of studies on behavioural addictions, mobile addiction amongst others. To date, addiction to MPs or nomophobia includes all that associated until not so long with Internet addiction (Ishii, 2004). For this reason, at the present, it should be considered a potentially multi-addictive platform with an endless range of reinforcement sources, which translates into high acceptance among the younger population (Walsh et al., 2010).

Behavioural addictions, such as pathological gambling, are characterized by the maintenance of the abusive behaviour despite the adverse consequences, as with drug addictions, where the shortterm reward is achieved with the intake of chemical substances. Something similar, from an emotional or neurological perspective, occurs with behavioural addictions (Clark \& Limbrick-Oldfield, 2013). To date, pathological gambling is the substance-unrelated addiction that has received the most attention and with the largest number of studies (Navas et al., 2017; Walther et al., 2012). An addictive behaviour implies the loss of the capacity to choose freely whether to quit or continue the behaviour (loss of control) and this leads to behaviour-related adverse consequences (Contreras-Rodríguez et al., 2016). In other words, the person is unable to predict with certainty when the behaviour will occur again, for how long, when it will stop, or which other behaviours can be linked with the addictive one. Consequently, other activities will be left aside, or if not, they will not be as pleasant as they once were. Other negative consequences of the addictive behaviour may include interference with life roles (e.g., work, social activities, or hobbies), deterioration of social relationships, legal problems, involvement in dangerous situations, physical lesions and deterioration, financial losses, and emotional problems. Various studies (Contreras-Rodríguez et al., 2016; Navas et al., 2017; Walther et al., 2012) hold the existence of similarities between pathological and substance-related addictions with regard to their phenomenology, epidemiology, personality factors, genetics, neurobiological processes, recovery, and management. Recently, an increasing number of studies (Müller et al., 2013; Pedrero-Pérez et al., 2012; Peirce et al., 2013) have found a series of potentially addictive behaviours. These behaviours are not linked with the use of substances but are a consequence of the technological society. Internet chats, compulsive shopping, pornography and/or addiction to sex, abuse of television, and/or addiction to MPs/nomophobia are the cause of many dependence cases in people that use these tools as a refuge that helps them escape 
from emotional or family problems. The behaviours are repetitive and pleasant at the beginning, but later the individual cannot control them. As previously mentioned, there are no specific and agreed diagnostic criteria for these types of addictions, although clinical experience exposes that excessive use of modern technologies is a real problem that affects certain people (Müller et al., 2013; Pedrero-Pérez et al., 2012; Peirce et al., 2013). History repeats itself. Pathological gambling was recognized as a nosological entity in 1980, when the APA introduced it under the name «pathological gambling» in its DSM (APA, 2003) which considered pathological gambling an Impulse-Control Disorder and the person who suffered it became (in a chronic and progressive manner) unable to resist the impulse of gambling, and classified with other disorders in the general section Impulse-Control Disorders Not Elsewhere Classified. Based on the above analysis, the purpose of the present study is to develop a Spanish measuring tool for nomophobia that will allow determining use vs abuse, type, frequency, and reason of MP use, time spent with the MP, motivations, abuse effects, no mobile effect, consequences of abuse, self-perception, and social perception.

\begin{abstract}
Methods
Participants

The sample for this survey included 968 participants of Granada population with a mean age of 23.19 years and a standard deviation of 7.23 . The majority of the respondents were women $(81.1 \%)$. The socio-demographic characteristics can be seen in Table 1. Participants were mainly recruited at their workplace, via recruitment stands, advertisements and emails. Their bosses/teachers were sent e-mails in which they were asked to help recruit their employees/students. It was their bosses/teachers who provided us with those employees/students willing to participate in the study. They were recruited from a range of types of workplace within Granada, including local authorities, healthcare providers and retail outlets as well as institutions of higher and further education, and there was heterogeneity in their geographical settings which spanned city centre and urban fringe locations. Participants were informed about the aims of the study and provided signed informed consent. Ethical approval was obtained from the Research Ethics Committee from University of Granada, Spain.
\end{abstract}

\title{
Sample and data collection
}

The sample size was estimated considering a $5 \%$ margin of error and a $95 \%$ confidence level. Nine hundred and sixty-eight young adults between 17 and 55 years were included in the survey. A summary of the sociodemographic characteristics is shown in Table 1.

Table 1

Sociodemographic variables summary

\begin{tabular}{lll}
\hline Variable & Mean & Std. Dev. \\
\hline Age & 23.19 & +-7.23 \\
\hline Years of education & 14.07 & +-4.12 \\
\hline Gender & Percentage & Size \\
\hline Male & & \\
\hline Female & $18.8 \%$ & $\mathrm{~N}=182$ \\
\hline Studying & $81.1 \%$ & $\mathrm{~N}=785$ \\
$\quad$ No & $21.1 \%$ & $\mathrm{~N}=204$ \\
$\quad$ Yes & $78.9 \%$ & $\mathrm{~N}=764$ \\
\hline Working & & \\
$\quad$ No & $81.3 \%$ & $\mathrm{~N}=787$ \\
$\quad$ Yes & $18.7 \%$ & $\mathrm{~N}=181$ \\
\hline Working sector & & $\mathrm{N}=32$ \\
\hline Technicians and business & $3.3 \%$ & $\mathrm{~N}=61$ \\
\hline Services and army & $6.3 \%$ & $\mathrm{~N}=87$ \\
$\quad$ Manual labour & $9.0 \%$ & $\mathrm{~N}=788$ \\
\hline Unemployment & $81.4 \%$ &
\end{tabular}

\section{Scale development and procedure}

In order to create a new Questionnaire to Assess Nomophobia (QANP), we conducted a systematic literature review (Beranuy-Fargues et al., 2009; Bianchi \& Phillips, 2005; Billieux et al., 2008; Chóliz, 2012; Chóliz et al., 2016; Güzeller \& Coşguner, 2012; Ha et al., 2008; Igarashi et al., 2008; Jenaro et al., 2007; Kwon et al., 2013; Leung, 2008; López-Fernández et al., 2012; Martinotti et al. 2011; Merlo et al., 2011; Rutland \& Sheets, 2007; Toda et al., 2004; Yildirim \& Correia, 2015) to examine the existing measuring 
instruments. Three experts in clinical psychology, educational psychology, and psychometrics worked in collaboration in the writing, understanding, clarification, and consistency of the criteria. Furthermore, we included items associated with nomophobia such as the consequences of not being able to use the mobile phone.

Once the new QANP was created, we conducted a pilot study and collected data from a heterogeneous small size sample representative of the target group; subjects were asked to express their feelings, ideas, and attitudes towards MP use. Initially, the scale was designed with 13 items, however, further experiments showed that only 11 could be used. The items were related with abuse in texting, high frequency, spending more than four hours per day using the MP (spending all the time with the MP), coping with negative emotions or problems, to feel better, extreme nervousness and aggressive behaviour when deprived from the MP or impossibility to use it, and progressive deterioration in school/ work and social and family functioning, impairment of social and self-perception.

We examined the scale to assess the psychometric properties of the individual items, as well as the scale as a whole. A numerical score from 1 to 5 was assigned to each item based on the use and abuse or nomophobia statement structure. Further description of the scale can be found in the Annex.

\section{Data Analysis}

Participants were randomly divided into two groups, each with $n=484$. One of the groups was used to perform an Exploratory Factor Analysis (EFA) and the other for a Confirmatory Factor Analysis (CFA) with the adjusted model obtained with the EFA. This data-driven approach is recommended when prior knowledge about possible common factors and their influences (Fabrigar et al., 1999) is insufficient. Several steps were followed before the EFA to prove the validity of the sample for building new variables. Bartlett's test for Sphericity was used to verify if the correlation matrix was equivalent to an identity matrix; the Kaiser-Meyer-Olkin (KMO) test was applied with a threshold of 0.8 (Kline, 1994) to test Measures of Sampling Adequacy (MSA).

For EFA rotation, a Promax algorithm was used which assumes obliquity between items. The reason behind this choice was to look for any strong relationship between the new factors, and if this were not the case, orthogonally between items was assumed. Maximum Likelihood (ML) was used for factoring, given that the results would be very similar to other factoring methods with the advantage of being able to observe a greater number of the goodness of fit indicators (Ferrando \& Anguiano-Carrasco, 2010). The EFA was conducted several times, with a threshold for standardized loadings of 0.30 each (Cattell, 1988; McDonald, 1985), in order to find an acceptable solution with the least number of dimensions. The acceptableness of this step was measured following the usual measures in scale validation, i.e., Root Mean Square Error of Approximation (RMSEA), which provides values below 0.05 if the adjustment is good, although values around 0.08 or below are indicators of an acceptable adjustment (Ruiz et al., 2010). Other measures included the Tucker-Lewis Index (TLI) of factoring reliability and the Root Mean Square of the Residuals (RMSR). Values above 0.95 for the TLI imply that the adjustment is good, but it can be considered acceptable if it is above 0.90 (Baş et al., 2016). Regarding the RMSR, values around the inverse of the square root of the sample size were considered indicators of a good adjustment (Kelley, 1935). We discarded the Chi-Square Test value, as high values would be frequently obtained due to the large sample size, which would result in misleading conclusions about the quality of the adjustment, even with trivial data-model differences (Fabrigar et al., 1999).

Considering the adjusted factorial model in the first step, and after assessing its nomological validity, a CFA was performed with the second group. To assess the goodness of fit in CFA, the same measures used in the EFA were used as well as the Goodness of Fit Index (GFI), which for good adjustments presents values around 0.95 .

Further calculations were performed in order to assess the validity and reliability, in its different dimensions (convergent, discriminant, and predictive), of the scale verified with the CFA. Cronbach's Alpha internal consistency coefficients were calculated for the items conforming each factor, whose values are considered to be acceptable when they are between 0.60 and 0.70 or higher (Baş, et al., 2016; Cronbach, 1949; Kelley, 1935). Item-total correlation was calculated for each item to verify that variations were homogeneous (Churchill, 1979). Student's t-tests were performed to evaluate the differences between upper and lower groups in each item.

The factors generated from the EFA and CFA were analyzed from the Item Response Theory (IRT) perspective using the Mokken scaling (Mokken, 1971). as an alternative to Classical Test Theory (CTT). This scaling allows the researcher to apply a type of non-parametric method to assess the validity of the scale, where the only assumption is that the answers are ordinal. The methods include the computerization of the coefficient of homogeneity as defined by Loevinger (1948) for each pair of items $\left(\mathrm{H}_{\mathrm{ij}}\right)$, 
each item $\left(H_{i}\right)$, and the entire scale $(H)$. A set of items were considered acceptable as per the criteria in (Mokken, 1971) if each $\mathrm{H}_{i j}>0$ and each $\mathrm{H}_{\mathrm{i}}>0.3$, implying $\mathrm{H}>0.3$. If all of these assumptions are met, a reliability coefficient rho (Molenaar \& Sijtsma, 1988) can be computed for the scale, which is comparable to Cronbach's alpha. Further information on this procedure can be consulted in (van Schuur, 2003). These calculations were made for all the data $(n=968)$.

Statistical analyses were carried out with the R program (R Core Team. 2015) and the packages psych (Revelle, 2017), lavaan (Rosseel, 2012), psychometric (Fletche, 2010), and mokken (van der Ark, 2012), besides the base libraries.

\section{Exploratory Factor Analysis}

\section{Results}

The EFA procedure was conducted on the first subsample to test the structure validity of the QANP regarding the measurement of mobile phone addiction. Prior to this procedure, Bartlett's test of Sphericity was applied to the subsample data. The null hypothesis of the test is $P=P_{0}$, where $P$ is the population item correlation matrix and $\mathrm{P}_{0}$ is the identity matrix. Results of the test rejected the null hypothesis $\left(X^{2}(n=484)=1242.549, d f=55, p<.0000\right)$ thus accepting the hypothesis that there is some sort of relationship between items. Sampling adequacy was assessed with KMO procedure, obtaining an overall MSA of 0.84 , which means that the joint relationship of the variables is adequate considering the threshold of 0.80 for MSA.

The conduction of the EFA provided as a result that the scale should have a structure of three factors with 11 items. Based on the criteria of the 0.30 threshold for standardized loadings, items 2 and 3 were dropped from the analysis (out of the original 13-item scale) as their contribution was not enough to fulfil the specified requirements. Factor 1 (Mobile Phone Abuse) consisted of five items (1, 3, 4,7 and 8 ) whose factor loadings rotated by Promax were in the range between 0.36 and 0.94 and explained a $19 \%$ of the variance. Factor 2 (Loss of Control) consisted of three items $(2,5$, and 6$)$ whose factor loadings rotated by Promax varied from 0.47 to 0.76 , explaining a $12 \%$ of the variance. Finally, Factor 3 (Negative Consequences) consisted of three items $(9,10$, and 11), with factor loadings rotated by Promax between 0.52 and 0.78 , which explained $10 \%$ of the variance. Further information about factor loadings with Promax rotation can be found in Table 2.

Table 2

Rotated factor loadings for the factors

\begin{tabular}{cccc}
\hline Items & Factor 1 & Factor 2 & Factor 3 \\
\hline 1 & 0.94 & -0.07 & -0.14 \\
2 & 0.11 & 0.68 & -0.01 \\
3 & 0.50 & -0.02 & -0.05 \\
4 & 0.36 & 0.06 & 0.16 \\
5 & -0.22 & 0.76 & -0.03 \\
6 & 0.22 & 0.47 & 0.03 \\
7 & 0.71 & 0.01 & -0.04 \\
8 & 0.52 & 0.09 & 0.08 \\
9 & -0.03 & 0.08 & 0.52 \\
10 & 0.11 & -0.10 & 0.52 \\
11 & -0.22 & -0.02 & 0.78 \\
\hline
\end{tabular}

The total variance explained by the scale was found to be $41 \%$, which could be remarked as sufficient in social science studies according to the author (Kline, 1994). RMSR index for EFA with three factors was 0.03 , meaning that few relationships are left to be explained thus the adjustment is good. Tucker-Lewis Index was 0.943, which is around the levels of acceptance, and the RMSEA index was 0.051 with a $90 \%$ confidence interval of [0.032 - 0.068], which is also within the limits of acceptance recommended by the references mentioned at Section 2.4. As a final remark for EFA, correlation matrix for factors can be observed in Table 3.

Table 3

Correlation coefficient between factors

\begin{tabular}{lccc}
\hline & Factor 1 & Factor 2 & Factor 3 \\
\hline Factor 1 & 1 & 0.63 & 0.55 \\
Factor 2 & 0.63 & 1 & 0.57 \\
Factor 3 & 0.55 & 0.57 & 1 \\
\hline
\end{tabular}


It is noticeable that correlations are numerically relevant; the correlation between Factor 1 and Factor 2 is 0.63 and between Factor 2 and Factor 3 is 0.55 . These numbers prove that the obliquity assumption is pertinent for the factor analysis performed.

A summary diagram for the factor loadings of each item, as well as the correlations between factors, can be observed in Figure 1.

Figure 1

Factor Analysis

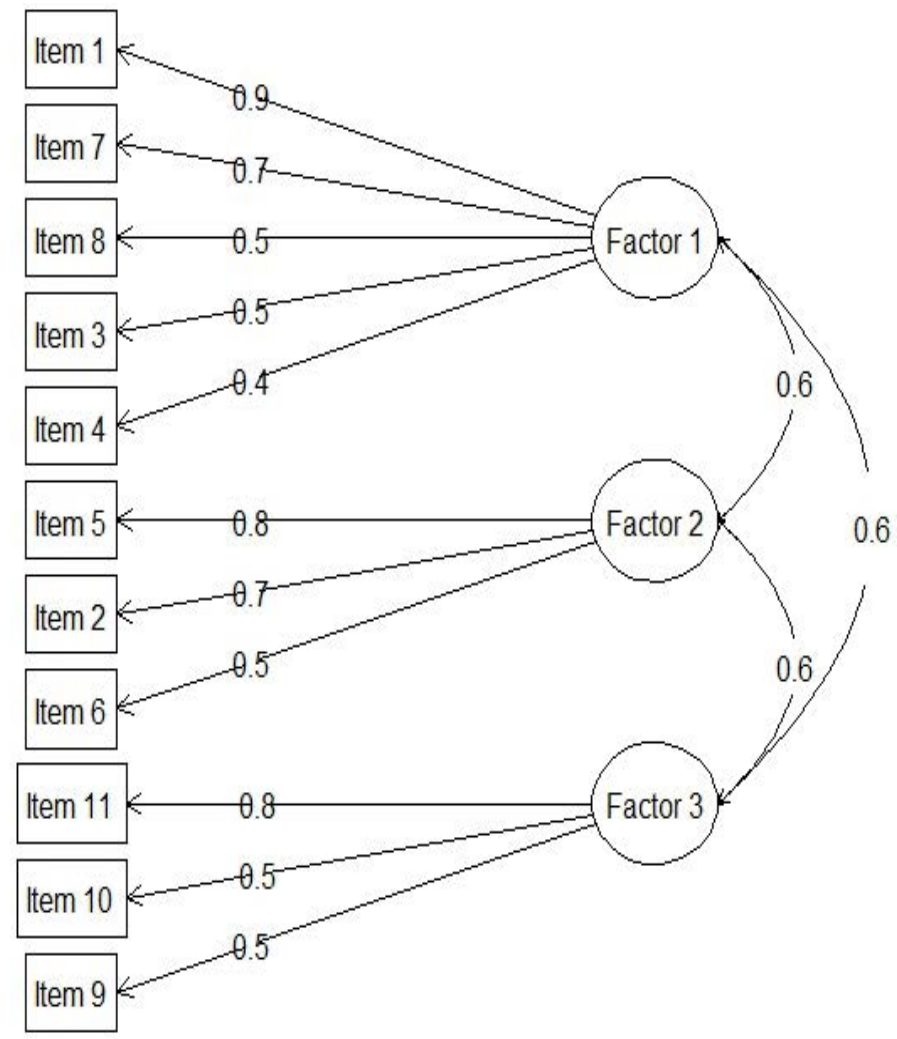

\section{Confirmatory Factor Analysis}

CFA was performed on the factor structure obtained in EFA, in order to verify it, on the second split $(\mathrm{n}=$ 484) done on the original sample. As a result, values for goodness-of-fit measures could be observed. SRMR was found out as 0.048 , which is very close to the inverse of the square root of the sample size (with $n=484$, the value is 0.04545455 ), so it can be considered as an evidence of a good fit. Goodness-of-Fit Index (GFI) was found to be 0.966 , which can be considered as evidence of a good fit as it is above 0.95 (the considered threshold of perfect fit). Tucker-Lewis Index (TLI) was found out at 0.936 , which is also above the threshold of acceptance. Finally, the RMSEA value was 0.055 , with a $90 \%$ confidence interval of [0.041-0.068]. Given that RMSEA indexes around 0.05 and 0.08 can be considered as sufficient, the value obtained for RMSEA in the CFA is also evidence of an acceptable fit.

\section{Questionnaire validity and reliability}

The result of Cronbach's Alpha calculation for measuring internal consistency of the whole scale and of all items was 0.80 . Furthermore, we calculated the internal consistency of each factor and the following coefficients were obtained: 0.75 for Factor 1, 0.64 for Factor 2, and 0.57 for Factor 3 . These values for reliability coefficients can be considered sufficient (Cronbach, 1949).

Convergent validity was assessed by calculating item-total correlation coefficients for each item. Table 4 shows the results accompanied by the mean and SD. Pearson's correlation test revealed that all correlations were significant with a confidence level above $99.99 \%$. In addition, differences of the means between items suggest unequal difficulty among them, which justifies the application of the Item Response Theory (IRT) analysis (van Schuur, 2003). 
Table 4

Items' summary statistics and item-total correlation

\begin{tabular}{cccc}
\hline Items & Mean & Std. Dev. & Item-total correlation \\
\hline 1 & 4.51 & 1.19 & 0.688 \\
2 & 2.57 & 1.35 & 0.701 \\
3 & 2.11 & 0.95 & 0.490 \\
4 & 2.42 & 1.23 & 0.596 \\
5 & 1.49 & 1.18 & 0.471 \\
6 & 2.45 & 1.25 & 0.672 \\
7 & 3.01 & 1.13 & 0.667 \\
8 & 2.52 & 0.95 & 0.632 \\
9 & 1.56 & 1.16 & 0.496 \\
10 & 1.48 & 0.81 & 0.514 \\
11 & 1.21 & 0.63 & 0.383 \\
\hline
\end{tabular}

To assess discriminant validity, t-tests were performed to analyse the differences between the groups with the lower $27 \%$ scores and the upper $27 \%$ scores for each item. The results of the tests can be consulted in Table 5 .

Table 5

Discriminant validity of the scale

\begin{tabular}{|c|c|c|c|c|c|c|c|}
\hline \multirow{2}{*}{ Item } & \multicolumn{2}{|c|}{ Upper $27 \%$} & \multicolumn{2}{|c|}{ Lower $\mathbf{2 7 \%}$} & \multirow{2}{*}{ t-value } & \multirow{2}{*}{$\begin{array}{l}\text { Degrees of } \\
\text { freedom }\end{array}$} & \multirow{2}{*}{ p-value } \\
\hline & Mean & Std. Dev. & Mean & Std. Dev. & & & \\
\hline Item 1 & 5 & 0 & 3.18 & 1.70 & 17.30 & 260 & $3.666244 \mathrm{E}-45$ \\
\hline Item 2 & 4.25 & 0.43 & 1 & 0 & 121.49 & 261 & $1.011690 \mathrm{E}-231$ \\
\hline Item 3 & 3.03 & 0.23 & 1 & 0 & 143.16 & 261 & 4.745320E-250 \\
\hline Item 4 & 4.14 & 0.35 & 1 & 0 & 144.29 & 261 & $6.337468 \mathrm{E}-251$ \\
\hline Item 5 & 2.80 & 1.66 & 1 & 0 & 17.56 & 261 & $4.277777 \mathrm{E}-46$ \\
\hline Item 6 & 4.00 & 1.79 & 1 & 0 & 61.26 & 261 & $6.562641 \mathrm{E}-157$ \\
\hline Item 7 & 4.30 & 0.46 & 1.59 & 0.87 & 44.25 & 392.317 & 1.303952E-154 \\
\hline Item 8 & 3.22 & 0.42 & 1.02 & 0.14 & 81.05 & 316.765 & 7.309143E-214 \\
\hline Item 9 & 3.04 & 1.36 & 1 & 0 & 24.28 & 261 & $6.569342 \mathrm{E}-69$ \\
\hline Item 10 & 2.51 & 0.82 & 1 & 0 & 29.59 & 261 & $2.277419 \mathrm{E}-85$ \\
\hline Item 11 & 1.75 & 0.99 & 1 & 0 & 12.27 & 261 & 1.271764E-27 \\
\hline
\end{tabular}

It can be observed in Table 5 that the upper group scores are significantly higher than lower group scores for every item of the scale, with a confidence level higher than $99.99 \%$. These results show that the items have good discriminant power.

\section{Mokken scaling}

Results of mokken scaling proved that the 11-item total scale is adequate; when analysed, every Hij coefficient for each pair of items (i, j) was above 0 , every Hi coefficient for each item i was above 0.30 (from item 1 to $11: 0.81,0.45,0.34,0.36,0.32,0.41,0.44,0.48,0.32,0.36$ and 0.32 respectively) and the total $\mathrm{H}$ coefficient was 0.413 .

The independent analysis of each factor also proved the validity of all of them. Factor 1 presented $\mathrm{Hij}>0$ for every pair of items in the factor and $\mathrm{Hi}>0.3$ for each item i $(0.67$ for item $7,0.82$ for item 1 , 0.54 for item 3, 0.82 for item 4, and 0.61 for item 8). The total $\mathrm{H}$ coefficient for Factor 1 was 0.537 . Factor 2 presented $\mathrm{Hij}>0$ for every pair of items in the factor and $\mathrm{Hi}>0.3$ for each item i $(0.55$ for item 2, 0.49 for item 5 and 0.44 for item 6 ). The total $\mathrm{H}$ coefficient for Factor 2 was 0.491 . Factor 3 presented $\mathrm{Hij}>0$ for every pair of items in the factor and $\mathrm{Hi}>0.3$ for each item i $(0.35$ for item $9,0.40$ for item 10 and 0.41 for item 11). The total $\mathrm{H}$ coefficient for Factor 3 was 0.383 . These results prove that the homogeneity of the QANP scale and its factors (subscales) was adequate, according to the criteria stipulated in Mokken (1971) for homogeneity coefficients.

Rho coefficient for the whole scale, calculated with the MS method, was 0.83 , while for Factors 1 , 2 and 3 was $0.78,0.65$ and 0.60 respectively. These reliability coefficients, comparable to Cronbach's alpha, prove that the proposed factor structure is reliable given that all the values are above acceptability thresholds (Cronbach, 1949). 


\section{Discussion}

The recognition of behavioural addictions goes back to Marlatt et al. (1988) who reported a repetitive habit pattern that increased the risk of disease and/or associated personal and/or social problems. Addictive behaviours are characterized by the loss of control. The behaviour is done again despite the volitional attempt of stopping or moderating it. Over the last decade a growing number of studies (Billieux et al., 2010; Mentzoni, et al., 2011) have established psychological and neurobiological similarities in the sustained practise of these behaviours (purchase, sex, Internet, video games, eating, MP overuse/ nomophobia). Neurobiological research on addiction has revealed the existence of a common mechanism between substance addiction and behavioural addictions (Leeman \& Potenza, 2013; Weinstein \& Lejoyeux, 2015). Regarding similarities between MP overuse/nomophobia and substance addiction, the results of different studies (Cheung \& Wong, 2011; Gao et al., 2018; Jenaro et al., 2007; Morissette et al., 2014; Ozturk et al., 2013; Reed et al., 2015; Thomée et al., 2011) indicate a variety of adverse effects for health, such as depression, social anxiety, insomnia, and hyperactivity. Further studies about these problems are necessary and specific tools to assess these constructs. i.e., nomophobia would facilitate our understanding. The primary goal of this study is to develop and validate a questionnaire to assess nomophobia. In this study, we also confirm a three-factor structure for an 11-item self-reported instrument to assess nomophobia.

The central point to be mentioned is that the confirmatory factor analysis emphasized that QANP has an acceptable fit and measures three factors. Factor 1 (Mobile Phone Abuse) consisted of five items $(1,3,4,7$ and 8$)$ as frequency use, bill pay, sleep interference, who to use the mobile phone with and effects, that describe a $19 \%$ of the variance. Factor 2 (Loss of Control) consisted of three items $(2,5$, and 6 ) as to cope negatives emotion or problems; aggressive behaviour, feel bad or depression when deprived or can't use that explain a $12 \%$ of the variance. Finally, Factor 3 (Negative Consequences) contains three items $(9,10$, and 11$)$ as to require help to abuse the mobile phone and explain a $10 \%$ the variance.

In this study, we confirmed and extended previous results regarding the symptoms proposed previously (Gao et al., 2018; Movvahedi et al., 2014; Szyjkowska et al., 2014; Thomée et al., 2011). Furthermore, the new results presented in this study can specifically be used to assess nomophobia, as there is, to the best of our knowledge, no other available tool for this purpose. In one study (Nagpal \& Kaur, 2016) gender differences in nomophobia and impulsiveness was examined, although there was no reference to the instrument used to assess nomophobia. Until now, it was only possible to assess MP addiction with the available instruments (Beranuy-Fargues et al., 2009; Bianchi \& Phillips, 2005; Billieux et al., 2008; Chóliz, 2012; Chóliz et al., 2016; Güzeller \& Coşguner, 2012; Ha et al., 2008; Igarashi et al., 2008; Jenaro et al., 2007; Kwon et al., 2013; Leung, 2008; López-Fernández et al., 2012; Martinotti et al. 2011; Merlo et al., 2011; Rutland and Sheets, 2007; Toda et al., 2004; Walsh et al., 2010; Yen et al., 2009).

The Cronbach' Alpha value was 0.80 . Internal consistency of each factor was 0.75 for Factor 1, 0.64 for Factor 2 and 0.57 for Factor 3. As stated (Cronbach, 1949), these values for reliability coefficients can be considered as sufficient. These results from the present study's investigation of the Instrument to Assess the Nomophobia (QANP) provide evidence that the measure is psychometrically sound.

The main research question of this study concerned an exploration of psychometric properties of the Questionnaire to Assess the Nomophobia (QANP), which provided solid evidence to support the reliability and validity of three subscales: Mobile Phone Abuse (Factor 1), Loss of Control (Factor 2), and Negative Consequences (Factor 3). Factor-based reliability indices including Cronbach's alphas were computed as a measure of internal consistency reliability. The Questionnaire to Assess the Nomophobia (QANP) was demonstrated to have good-to-excellent reliability. Content validity was supported by the use of an expert panel review process in generation of scale items.

Evidence of convergent validity was demonstrated in the strong positive correlations between item-total correlation coefficients. Discriminant validity was further supported by the evidence of statistically significant differences between the groups with the lower $27 \%$ scores and the upper $27 \%$ scores for each item.

Item Response Theory analysis also provided results which proved the validity and the homogeneity of the scale. Homogeneity coefficients were above the acceptability thresholds, and reliability coefficients computed using the MS approach provided adequate results.

Regarding the clinical implications, the development of the QANP to detect MP overuse is an important step for the development of diagnostic/therapeutic procedures and prevention/intervention strategies. Future studies should examine the relationships between variables such as solitude, depression, self-esteem, well-being, academic success, and other demographic features, with nomophobia. 
Further understanding of nomophobia will provide additional data to be included in the DSM criteria, particularly when referring to addictions linked to modern age technologies. Moreover, certain construct validity evidence should be reviewed. Gender and age group invariance analyses are necessary to obtain empirical evidence on the equivalence in the constructs and items used in the QANP. Once the above is guaranteed, Differential Item Functioning and thorough comparative analysis of the considered variables will be necessary to ensure the validity of the decisions through the scorings in the tests. With these results, a score $\geq 40$ or above could be considered as a high level of Nomophobia.

\section{Limitations and future research}

Our results should be evaluated in view of several important limitations. First, nomophobia should be investigated considering a number of variables, such as demographics, personality, and clinical characteristics. This would allow a better understanding of human-technology interactions, as well as the nature and causes of technology-related addictions. To the best of our knowledge, to date, there is no valid and reliable questionnaire to measure nomophobia. The questionnaire presented in this study (QANP) is an adequate instrument to measure MP addiction in future investigations on this modern disorder although this is a self-reported measure and consequently unmeasured potential confounders. Some people are interested in a therapeutic change and admit having negative personality features, but have a very positive image. Thus, a second limitation to our study is the accuracy of participant self-reported responses

Future studies should be carried out to elucidate the mechanisms underlying problematic MP use and determine whether it is a primary phenomenon or a symptom of underlying pathology (e.g., anxiety disorders, impulse control deficits, personality factors). Long-term research on nomophobia should focus on the identification and treatment of problematic users or those at risk. Nomophobia should be classified as an important pathology. This would allow maximizing MP usefulness while minimizing the damaging consequences of high frequency of texting, overuse, spending more than four hours per day with the MP (spending all the time with the MP), coping with negative emotions or problems, to feel better, extreme nervousness and aggressive behaviour when deprived from the MP or impossibility to use it, and progressive deterioration in school/work and social and family functioning, impairment of social and self-perception. Further evaluation and definition of nomophobia will allow developing interventions or prevention programs.

\section{Role of funding sources}

We would like to thank all of the participants in this study. This research was partially supported by Ministerio de Educación, Cultura y Deporte (grant MTM2015-63609-R Spain).

\section{Acknowledgements}

We would like to thank all participants for their contribution in this study.

\section{References}

1. Aggarwal, K. K., (2010). Twenty-six percent doctors suffer from severe mobile phone-induced anxiety: excessive use of mobile phone can be injurious to your health. International Journal Clinical Practice, 24, 7-9.

2. Ali, M., Asim, M., Danish, S. H., Ahmad, F., Iqbal, A., \& Hasan, S. D. (2014). Frequency of De Quervain's tenosynovitis and its association with SMS texting. Muscles, Ligaments and Tendons Journal, 4, 74-78. https://doi.org/10.11138/mlti/2014.4.1.074

3. American Psychiatric Association (APA). (1980). Diagnostic and Statistical Manual of Mental Disorders ( $3^{\mathrm{a}}$ ed.) (DSM-III). Washington, DC: APA,

4. American Psychiatric Association (APA). (2002). Diagnostic and Statistical Manual of Mental Disorders IV-TR (DSM-IV-TR). Washington, DC: APA.

5. American Psychiatric Association (APA, 2013). (2013). Diagnostic and Statistical Manual of Mental Disorders (DSM-5). Washington, DC: APA, 2013. https://doi.org/10.1176/appi. books.9780890425596

6. Asensio-Chico, I., Díaz-Maldonado, L., \& Garrote-Moreno, L. (2018). Nomophobia: Disorder of the 21st Century. Semergen, 44, 117-e118. https://doi.org/10.1016/j.semerg.2018.05.002

7. Baş, G., Kubiatko, M., \& Sünbül, A.M. (2016). Teachers' perceptions towards ICTs in teaching-learning process: Scale validity and reliability study. Computer Human Behaviour, 61, 176-185. https://doi.org/10.1016/j.chb.2016.03.022 
8. Beranuy-Fargues, M., Chamarro-Lusar, A., Graner-Jordania, C., \& Carbonell-Sánchez, X. (2009). Validation of two brief scales for internet addiction and mobile phone problem use. Psicothema, $21,480-485$.

9. Bianchi, A., \& Phillips, J.G., (2005). Psychological predictors of problem mobile phone use. Cyberpsychology Behaviour, 8, 39-51. https://doi.org/10.1037/t58633-000

10. Billieux, J., Gay, P., Rochat, L., \& Van Der Linden, M. (2010). The role of urgency and its underlying psychological mechanisms in problematic behaviours. Behavior Research Therapy, 48, 1085-1096. https://doi.org/10.1016/j.brat.2010.07.008

11. Billieux, J., Van, D.L., \& Rochat, L. (2008). The role of impulsivity in actual and problematic use of the mobile phone. Applied Cognitive Psychology, 22, 1195-1210. https://doi.org/10.1002/acp.1429

12. Bragazzi, N.L., \& Del Puente, G. (2014). A proposal for including nomophobia in the new DSM-5. Psychology Research and Behavior Management, 16, 155-160. https://doi.org/10.2147/PRBM. S41386

13. Cattell, R.B. (1988). The meaning and strategic use of factor analysis. In J.R. Nesselroade and R.B. Cattell (eds.) Handbook of multivariate experimental psychology (pp.131-203). New York: Plenum Press. https://doi.org/10.1007/978-1-4613-0893-5_4

14. Cheung, L. M., \& Wong, W. S. (2011). The effects of insomnia and internet addiction on depression in Hong Kong Chinese adolescents: An exploratory cross-sectional analysis. Journal of Sleep Research, 20, 311-317. https://doi.org/10.1111/j.1365-2869.2010.00883.x

15. Chóliz, M. (2010). Mobile phone addiction: a point of issue. Addiction, 105, 373-374. https://doi. org/10.1111/j.1360-0443.2009.02854.x

16. Chóliz, M. (2012). Mobile-phone addiction in adolescence: The test of mobile phone dependence (TMD). Program in Health Science, 2, 33-44.

17. Chóliz, M., Pinto, L., Phansalkar, S.S., Corr, E., Mujjahid, A., Flores, C., \& Barrientos, P.E. (2016). Development of a Brief Multicultural Version of the Test of Mobile Phone Dependence (TMD brief) Questionnaire. Frontiers in Psychology, 25, 1-10. https://doi.org/10.3389/fpsyg.2016.00650

18. Churchill, J.R.G.A. (1979). A paradigm for developing better measures of marketing constructs. Journal of Marketing Research, 16, 64-73. https://doi.org/10.2307/3150876

19. Clark, L., \& Limbrick-Oldfield, E. H. (2013). Disordered gambling: a behavioral addiction. Current Opinion Neurobiology, 23, 655-659. https://doi.org/10.1016/j.conb.2013.01.004

20. Contreras-Rodríguez, O., Albein-Urios, N., Vilar-López, R., Perales, J. C., Martínez-González, J. M., Fernández-Serrano, M. J., Lozano-Rojas, O., Clarke, L., \& Verdejo-García, A., (2016). Increased corticolimbic connectivity in cocaine dependence versus pathological gambling is associated with drug severity and emotion-related impulsivity. Addiction Biology, 21, 709-718. https://doi.org/10.1111/adb.12242

21. Cronbach, L.J., (1949). Essentials of psychological testing, Harper: Oxford, UK,

22. De-Sola, J., Rodríguez-De Fonseca, F., \& Rubio, G. (2016). Cell-phone addiction: A review. Frontiers in Psychiatry, 175, 1-15. https://doi.org/10.3389/fpsyt.2016.00175

23. Dixit, S., Shukla, H., Bhagwat, A., Bindal, A., Goyal, A., Zaidi, A.K., \& Shrivastava, A. (2010). A study to evaluate mobile phone dependence among students of a medical college and associated hospital of central India. Indian Journal Community Medicine, 35, 339-341. https://doi. org/10.4103/0970-0218.66878

24. Fabrigar, L.R., Wegener, D.T., Maccallum, R.C., \& Strahan, E.J. (1999). Evaluating the use of exploratory factor analysis in psychological research. Psychological Methods, 4, 272-299. https:// doi.org/10.1037/1082-989X.4.3.272

25. Ferrando, P.J., \& Anguiano-Carrasco, C. (2010). El Análisis factorial como técnica de investigación en psicología. Papeles del Psicólogo, 31, 18-33.

26. Fletche, T.D. (2010). Psychometric. Applied Psychometric Theory. R package version 2.2. http:// CRAN.R-project.org/package=psychometric (Acceded 9 Sep 2016).

27. Foerster, M., Roser, K., Schoeni, A., \& Röösli, M. (2015). Problematic mobile phone use in adolescents: Derivation of a short scale MPPUS-10. International Journal of Public Health, 60, 277-286. https://doi.org/10.1007/s00038-015-0660-4

28. Forgays, D.K., Hyman, I., \& Schreiber, J. (2014). Texting everywhere for everything: Gender and age differences in cell phone etiquette and use. Computer Human Behaviour, 2, 314-321. https:// doi.org/10.1016/j.chb.2013.10.053

29. Gao, T., Li, J., Zhang, H., Gao, J., Kong, Y., Hu, Y., \& Mei, S. (2018). The influence of alexithymia on mobile phone addiction: The role of depression, anxiety and stress. Journal Affective Disorders, 225, 761-766. https://doi.org/10.1016/j.jad.2017.08.020 
30. Güzeller, C.O., \& Coşguner, T. (2012). Development of a problematic mobile phone use scale for Turkish adolescents. Cyberpsychology Behaviour Social Networking, 15, 205-211. https://doi. org/10.1089/cyber.2011.0210

31. Ha, J.H., Chin, B., Park, D.H., Ryu, S.H., \& Yu, J. (2008). Characteristics of excessive celular phone use in Korean adolescents. Cyberpsychology Behaviour Social Networking, 11, 783-784. https://doi.org/10.1089/cpb.2008.0096

32. Igarashi, T., Motoyoshi, T., Takai, J., \& Yoshida, T. (2008). No mobile, no life: Self-perception and text-message dependency among Japanese high school students. Computers Human Behavior, 24, 2311-2324. https://doi.org/10.1016/j.chb.2007.12.001

33. Ishii, K. (2004). Internet use via mobile phone in Japan. Telecommunications Policy, 28, 43-58. https://doi.org/10.1016/j.telpol.2003.07.001

34. Jenaro, C., Flores, N., Gómez-Vela, M., González-Gil, F., \& Caballo, C. (2007). Problematic internet and cell-phone use: Psychological behavioral, and health correlates. Addictive Research Theory, 15, 309-320. https://doi.org/10.1080/16066350701350247

35. Kelley, T.L., (1935). Essential Traits of Mental Life, Harvard Studies in Education, Harvard University Press: Cambridge, UK.

36. King, A.L.S., Valença, A.M., Silva, A.C., Sancassiani, F., Machado, S., \& Nardi, A.E. (2014). Nomophobia: Impact of cell phone use interfering with symptoms and emotions of individuals with panic disorder compared with a control group. Clinical Practice \& Epidemiology Mental Health, 10, 28-35. https://doi.org/10.2174/1745017901410010028

37. Kline, P. (1994). An easy guide to factor analysis. Routledge: New York, USA.

38. Kuss, D.J., \& Griffiths, M.D. (2016). Online social networking and addiction a review of the psychological literature. International Journal Environmental Research and Public Health, 8, 3528-3552. https://doi.org/10.3390/ijerph8093528

39. Kwon, M., Lee, J.Y., Won, W.Y., Park, J.W., Min, J.A., Hahn, C., Gu, X., Choi, J.H., \& Kim, D.J. (2013). Development and validation of a smartphone addiction scale (SAS). PLoS One. 8(2): e56936. https://doi.org/10.1371/journal.pone.0056936

40. Leeman, R. F., \& Potenza, M. N. (2013). A targeted review of the neurobiology and genetics of behavioural addictions: An emerging area of research. Canadian Journal Psychiatry, 58, 260273. https://doi.org/10.1177/070674371305800503

41. Lin, Y. H., Lin, S. H., Li, P., Huang, W. L., \& Chen, C. Y. (2013). Prevalent hallucinations during medical internships: phantom vibration and ringing syndromes. PLoS One, 8(6): e65152. https:// doi.org/10.1371/journal.pone.0065152

42. Loevinger, J. (1948). The Technique of Homogeneous Tests Compared with Some Aspects of 'Scale Analysis' and Factor Analysis. Psychological Bulletin, 45, 507-530. https://doi.org/10.1037/ h0055827

43. Leung, L. (2008). Linking psychological attributes to addiction and improper use of the mobile phone among adolescents in Hong Kong. Journal Child Media, 2, 93-113. https://doi. org/10.1080/17482790802078565

44. López-Fernández, O., Honrubia-Serrano, M., \& Freixa-Blanxart, M. (2012). Adaptación española del "Mobile Phone Problem Use Scale" para población adolescente. Adicciones. 24, 123-130. https://doi.org/10.20882/adicciones.104

45. Marlatt, G. A., Baer, J. S., Donovan, D. M., \& Kivlahan, D. R. (1988). Addictive behaviors: Etiology and treatment. Annual Review Psychology, 39, 223-252. https://doi.org/10.1136/ bmjopen-2013-003440

46. Martinotti, G., Villella C., Di Thiene, D., Di Nicola, M., Bria, P., Conte, G., Cassano, M., Corcasce, F., Janiri, L., \& La Torre, G., (2011). Problematic mobile phone use in adolescence: A cross-sectional study. Journal Public Health, 19, 545-561. https://doi.org/10.1007/s10389-011-0422-6

47. Mcdonald, R.P. (1985). Factor analysis and related methods, Hillsdale, LEA: New Jersey, NY. USA

48. Mentzoni, R. A., Brunborg, G. S., Molde, H., Myrseth, H., Mår Skouverøe, K. J., Hetland, J., \& Pallesen, S. (2011). Problematic video game use: Estimated prevalence and associations with mental and physical health. Cyberpsychology Behavior and Social Networking, 14, 591-596. https://doi.org/10.1089/cyber.2010.0260

49. Merlo, L.J., Stone, A.M., \& Bibbey, A. (2011). Measuring problematic mobile phone use: Development and preliminary psychometric properties of the PUMP scale. Journal Addiction, 1-7, 912807. https://doi.org/10.1155/2013/912807 
50. Mokken, R. J., (1971). A Theory and Procedure of Scale Analysis with Applications in Political Research, De Gruyter: New York, USA. https://doi.org/10.1515/9783110813203

51. Molenaar, I. W., \& Sijtsma, K. (1988). Mokken's approach to reliability estimation extended to multicategory items. Kwantitatieve Methoden, 9, 115-126.

52. Morissette, A., Ouellet-Plamondon, C., \& Jutras-Aswad, D. (2014). Craving as a core symptom in substance use disorders: Epidemiology, neurobiological substrates and clinical relevance. Sante Mentale Quebec, 39, 21-37. https://doi.org/10.7202/1027830ar

53. Movvahedi, M.M., Tavakkoli-Golpayegani, A., Mortazavi, S.A., Haghani, M., Razi, Z., Shojaie-Fard, M.B., Zare, M., Mina, E., Mansourabadi, L., Nazari-Jahromi, S. A.; Shokrpour, N., \& Mortazavi, S.M. (2014). Does exposure to GSM $900 \mathrm{MHz}$ mobile phone radiation affect short-term memory of elementary school students? Journal Pediatric Neuroradiology, 9, 121-124. https://doi. org/10.4103/1817-1745.139300

54. Müller, K.W., Koch, A., Dickenhorst, U., Beutel, M. E., Duven, E., \& Wölfling, K. (2013). Addressing the question of disorder-specific risk factors of internet addiction: A comparison of personality traits in patients with addictive behaviors and comorbid internet addiction. Biomedicine Research International, 546342, 1-7. https://doi.org/10.1155/2013/546342

55. Nagpal, S.S., \& Kaur, R., (2016). Nomophobia: The problem lies at our fingertips. Indian Journal of Health \& Wellbeing, 12, 1135-1139.

56. Navas, J. F., Billieux, J., Perandrés-Gómez, A., López-Torrecillas, F., Cándido, A., \& Perales, J. C. (2017). Impulsivity traits and gambling cognitions associated with gambling preferences and clinical status. International Gambling Studies, 17, 102-124. https://doi.org/10.1080/14459795.2 016.1275739

57. Pedrero-Pérez, E. J., Rodríguez-Monje, M. T., \& Ruiz-Sánchez- De León, J. M., (2012). Mobile phone abuse or addiction. A review of the literature. Adicciones, 24, 139-152. https://doi. org/10.20882/adicciones.107

58. Peirce, J. M., Brooner, R. K., Kolodner, K., Schacht, R. L., \& Kidorf, M. S. (2013). Prospective effects of traumatic event re-exposure and post-traumatic stress disorder in syringe exchange participants. Addiction, 108, 146-153. https://doi.org/10.1111/j.1360-0443.2012.04003.x

59. Ozturk, F. O., Ekinci, M., Ozturk, O., \& Canan, F. (2013). The relationship of affective temperament and emotional-behavioral difficulties to internet addiction in Turkish teenagers. International Scholarly Research Notices Psychiatry, 28, 1-6. http://dx.doi.org/10.1155/2013/961734.

60. Revelle, W. (2015). Psych: Procedures for Personality and Psychological Research, Northwestern University Evanston: Illinois, USA. http://CRAN.R-project.org/package=psych Version = 1.5.8. (Accessed 7 Ene 2017).

61. Rosseel, Y. (2012). lavaan: An R Package for Structural Equation Modeling. Journal of Statistical Software, 48, 1-36. https://doi.org/10.18637/jss.v048.i02

62. Ruiz, M.A., Pardo, A., \& San Martín, R. (2010). Modelos de Ecuaciones Estructurales. Papeles del Psicólogo. 31, 18-33.

63. Rutland, J.B., Sheets, T., \& Young, T., (2007). Development of a scale to measure problem use of short message service: the SMS Problem Use Diagnostic Questionnaire. Cyberpsychology and Behavior, 10, 841-843. https://doi.org/10.1089/cpb.2007.9943

64. Sánchez-Carbonell, X., Beranuy, M., Castellana, M., Chamarro, A., \& Oberst, U. (2008). La adicción a Internet y al móvil: ¿moda o trastorno? Adicciones, 20, 149-160. https://doi.org/10.20882/ adicciones. 279

65. Stothart, C., Mitchum, A., \& Yehnert, C. (2015). The attentional cost of receiving a cell phone notification. The Journal Experimental Psychology Human Perceptual Performance, 41, 893-897. https://doi.org/10.1037/xhp0000100

66. Szyjkowska, A., Gadzicka, E., Szymczak, W., \& Bortkiewicz, A. (2014). The risk of subjective symptoms in mobile phone users in Poland: An epidemiological study. International Journal Environmental Research and Public Health, 2, 293-303. https://doi.org/10.2478/s13382-014-0260-1

67. Reed, K., Day, E., Keen, J., \& Strang, J. (2015). Pharmacological treatments for drug misuse and dependence. Expert Opinion Pharmacotherapy Journal, 16, 325-333. https://doi.org/10.1517/14 656566.2015 .983472

68. Toda, M., Monden, K., Kubo, K., \& Morimoto, K. (2004). Cellular phone dependence tendency of female university students. Japanese Journal of Hygiene, 59, 383-86. https://doi.org/10.1265/ i⿺辶. 59.383

69. Thomée, S., Härenstam, A., \& Hagberg, M. (2011). Mobile phone use and stress, sleep disturbances, and symptoms of depression among young adults - a prospective cohort study. BMC Public Health, 11, 66-77. http://dx.doi.org/10.1186/1471-2458-11-66. 
70. Van Der Ark, L. A. (2012). New Developments in Mokken Scale Analysis in R. Journal of Statistical Software. 48, 1-27. https://doi.org/10.18637/jss.v048.i05

71. Van Schuur, W. H. (2003). Mokken Scale Analysis: Between the Guttman Scale and Parametric Item Response Theory. Political Analyst, 11, 139-163. https://doi.org/10.1093/pan/mpg002

72. Verma, R. K., Rajiah, K., Cheang, A., \& Barua, A. (2014). Textaphrenia: An emerging silent pandemic. African Journal Psychiatry, 17, 510-511. https://doi.org/10.4172/Psychiatry.1000e103

73. Višnjić, A., Veličković, V., Sokolović, D., Stanković, M., Mijatović, K., Stojanović, M., Milošević, Z., \& Radulović, O. (2018). Relationship between the Manner of Mobile Phone Use and Depression, Anxiety, and Stress in University Students. International Journal Environmental Research and Public Health, 15, 697-708. https://doi.org/10.3390/ijerph15040697

74. Yen, C.F., Tang, T.C., Yen, J.Y., Lin, H.C., Huang, C.F., Liu, S.C., \& Ko, C.H. (2009). Symptoms of problematic cellular phone use, functional impairment and its association with depression among adolescents in Southern Taiwan. Journal of Adolescence, 32, 863-873. https://doi.org/10.1016/j. chb.2015.02.059

75. Yildirim, C., \& Correia, A.P. (2015). Exploring the dimensions of nomophobia: Development and validation of a self-reported questionnaire. Computers in Human Behavior, 49,130-137. https:// doi.org/10.1016/j.chb.2015.02.059

76. Walsh, S.P., White, K.M., \& Young, R. (2010). Needing to connect: The effect of self and others on young people's involvement with their mobile phones. Australian Journal of Psychology, 62, 194-203. https://doi.org/10.1080/00049530903567229

77. Walther, B., Morgenstern, M., \& Hanewinkel, R. (2012). Co-occurrence of addictive behaviours: Personality factors related to substance use, gambling and computer gaming. European Addiction Research, 18,167-174. https://doi.org/10.1159/000335662

78. Weinstein, A., \& Lejoyeux, M. (2015). New developments on the neurobiological and pharmaco-genetic mechanisms underlying internet and videogame addiction. American Journal of Addiction, 24, 117-125. https://doi.org/10.1111/ajad.12110

RECIBIDO: 14 de octubre de 2019 MODIFICADO: 25 de enero de 2020 ACEPTADO: 22 de junio de 2020 
Annex. Questionnaire to Assess the Nomophobia (QANP)

\begin{tabular}{|c|c|c|c|c|c|c|}
\hline & Question about use mobile phone & Response categories & & & & \\
\hline & & 1 & 2 & 3 & 4 & 5 \\
\hline 101 & How often do you use mobile phone use? & $\begin{array}{l}\text { Twice more over } \\
\text { month }\end{array}$ & Weekend & Daily & Two hours a day & $\begin{array}{l}\text { More than four hours } \\
\text { a day. }\end{array}$ \\
\hline 102 & What are you raison for use mobile phone? & Feeling happy & Look up to my friends & Enjoy whit it & $\begin{array}{l}\text { Coping stress and } \\
\text { problem }\end{array}$ & $\begin{array}{l}\text { Coping sadness, } \\
\text { loneliness and } \\
\text { compassion myself }\end{array}$ \\
\hline 103 & How do you pay bill? & Wage & Credit card & Family & Partner & Stolen \\
\hline 104 & What time do you use the mobile phone? & At night & After class or work & During class or work & $\begin{array}{l}\text { Morning, when I } \\
\text { wake up }\end{array}$ & $\begin{array}{l}\text { I get up at night and } \\
\text { use it }\end{array}$ \\
\hline 105 & Why do you use mobile phone? & $\begin{array}{l}\text { To communicate with } \\
\text { my friends }\end{array}$ & I feel lonely & $\begin{array}{l}\text { Because my friends } \\
\text { use it }\end{array}$ & To escape my problem & To quit the routine \\
\hline 106 & Sometimes happens that & $\begin{array}{l}\text { I trouble keeping } \\
\text { up with my mobile } \\
\text { phone's friends }\end{array}$ & $\begin{array}{l}\text { It's difficult for me to } \\
\text { answer when I receive } \\
\text { messages / whatsapps }\end{array}$ & $\begin{array}{l}\text { I persistently call the } \\
\text { same person }\end{array}$ & $\begin{array}{l}\text { I feel sad when they } \\
\text { do not answer me }\end{array}$ & $\begin{array}{l}\text { I get depressed or } \\
\text { irritated if I can't use } \\
\text { my mobile phone }\end{array}$ \\
\hline 107 & Who do you use your mobile phone? & Parents or Family & Brothers and sisters & Partner & Friends & Strangers \\
\hline 108 & $\begin{array}{l}\text { How do you feel when you use your mobile } \\
\text { phone? }\end{array}$ & I feel well and relaxed & I feel euphoric & $\begin{array}{l}\text { In connection with my } \\
\text { friends }\end{array}$ & Heavy and sick & $\begin{array}{l}\text { Absolutely lost, if I } \\
\text { couldn't use it }\end{array}$ \\
\hline 109 & What are the consequences of using? & Neither & $\begin{array}{l}\text { Social relations } \\
\text { problem }\end{array}$ & $\begin{array}{l}\text { I lost out on having a } \\
\text { lot of good times }\end{array}$ & Economic problem & $\begin{array}{l}\text { Family and/or partner } \\
\text { problem }\end{array}$ \\
\hline 110 & $\begin{array}{l}\text { How do you feel about your mobile phone } \\
\text { using? }\end{array}$ & I haven't problem & I can control & $\begin{array}{l}\text { I can control but I'm } \\
\text { using by my friends }\end{array}$ & $\begin{array}{l}\text { I feel bad when I think } \\
\text { of using }\end{array}$ & $\begin{array}{l}\text { I need help or } \\
\text { treatment }\end{array}$ \\
\hline 111 & $\begin{array}{l}\text { How do you perceive others about your } \\
\text { using? }\end{array}$ & Normal on my age & $\begin{array}{l}\text { When I use neglect my } \\
\text { family responsibilities }\end{array}$ & $\begin{array}{l}\text { When I use neglect my } \\
\text { friends responsibilities }\end{array}$ & $\begin{array}{l}\text { My family or friends } \\
\text { advises me to control } \\
\text { using }\end{array}$ & $\begin{array}{l}\text { My family or friends } \\
\text { advises me to } \\
\text { treatment }\end{array}$ \\
\hline
\end{tabular}

Spanish Version. Questionnaire to Assess the Nomophobia (QANP)

\begin{tabular}{|c|c|c|c|c|c|c|}
\hline & $\begin{array}{l}\text { Preguntas acerca del uso del teléfono } \\
\text { móvil }\end{array}$ & Categorías de Respue & stas & & & \\
\hline & & 1 & 2 & 3 & 4 & 5 \\
\hline 101 & $\begin{array}{l}\text { ¿Cuántas veces utilizas el teléfono } \\
\text { móvil? }\end{array}$ & 203 veces al mes & Semanalmente & Diariamente & 2 horas al día & Más de 4 horas al día \\
\hline 102 & $\begin{array}{l}\text { Señala las razones que tienes para usar el } \\
\text { teléfono móvil }\end{array}$ & Sentirme feliz & Ser como mis amigos & Divertirme & $\begin{array}{l}\text { Evadirme de mis } \\
\text { problemas y estrés }\end{array}$ & $\begin{array}{l}\text { Salir de mi tristeza, } \\
\text { soledad y lastima de } \\
\text { mí mismo/a }\end{array}$ \\
\hline 103 & $\begin{array}{l}\text { ¿Cómo consigues pagar la factura } \\
\text { del teléfono móvil? }\end{array}$ & Trabajando & $\begin{array}{l}\text { Con la tarjeta de } \\
\text { crédito }\end{array}$ & De mi familia & De mi pareja & Robando \\
\hline 104 & $\begin{array}{l}\text { ¿A qué hora del día sueles usar el } \\
\text { teléfono móvil? }\end{array}$ & Por la noche & $\begin{array}{l}\text { Después de salir de } \\
\text { clase o del trabajo }\end{array}$ & $\begin{array}{l}\text { Durante las clases } 0 \\
\text { el trabajo }\end{array}$ & $\begin{array}{l}\text { Por la mañana, } \\
\text { cuando me despierto }\end{array}$ & $\begin{array}{l}\text { Me levanto durante la } \\
\text { noche y lo suelo usar }\end{array}$ \\
\hline 105 & ¿Por qué usas el teléfono móvil? & $\begin{array}{l}\text { Para comunicarme } \\
\text { con mis amigos/as }\end{array}$ & $\begin{array}{l}\text { Porque me siento } \\
\text { solola }\end{array}$ & $\begin{array}{l}\text { Porque mis amigos } \\
\text { lo usan }\end{array}$ & $\begin{array}{l}\text { Para evadirme de mis } \\
\text { problemas }\end{array}$ & Para salir de la rutuna \\
\hline 106 & A veces me ocurre que... & $\begin{array}{l}\text { Me cuesta seguir } \\
\text { el ritmo del uso del } \\
\text { teléfono móvil con mis } \\
\text { amigos }\end{array}$ & $\begin{array}{l}\text { Me cuesta contestar } \\
\text { mensajes/whatsapps }\end{array}$ & $\begin{array}{l}\text { Llamo de manera } \\
\text { persistente a la misma } \\
\text { persona }\end{array}$ & $\begin{array}{l}\text { Me siento triste } \\
\text { cuando no me } \\
\text { contestan }\end{array}$ & $\begin{array}{l}\text { Me deprimo o irrito } \\
\text { si no puedo usar el } \\
\text { teléfono móvil }\end{array}$ \\
\hline 107 & ¿Con quién usas el teléfono móvil? & $\begin{array}{l}\text { Con mis padres } 0 \\
\text { familiares }\end{array}$ & $\begin{array}{l}\text { Con mis hermanos } 0 \\
\text { hermanas }\end{array}$ & Con mi pareja & Con mis amigos & Con desconocidos \\
\hline 108 & $\begin{array}{l}\text { ¿Qué sientes cuando usas el } \\
\text { teléfono móvil? }\end{array}$ & $\begin{array}{l}\text { Sensación de } \\
\text { bienestar y relajación }\end{array}$ & Sensación de euforia & $\begin{array}{l}\text { Conectado con los } \\
\text { amigos/as }\end{array}$ & $\begin{array}{l}\text { Muy pesado/a } \\
\text { como si sufriera una } \\
\text { enfermedad }\end{array}$ & $\begin{array}{l}\text { Totalmente perdido/a, } \\
\text { si no lo pudiera usar }\end{array}$ \\
\hline 109 & $\begin{array}{l}\text { ¿Cuáles han sido las } \\
\text { consecuencias del uso del teléfono } \\
\text { móvil a lo largo de tu vida? }\end{array}$ & Ninguna & $\begin{array}{l}\text { Ha interferido en mis } \\
\text { relaciones sociales }\end{array}$ & $\begin{array}{l}\text { Ha evitado que tenga } \\
\text { buenos momentos }\end{array}$ & $\begin{array}{l}\text { Me he visto en apuros } \\
\text { económicos }\end{array}$ & $\begin{array}{l}\text { He tenido problemas } \\
\text { con mis padres y/o } \\
\text { pareja }\end{array}$ \\
\hline 110 & $\begin{array}{l}\text { ¿Cómo te sientes cuando te } \\
\text { planteas tu uso de teléfono móvil? }\end{array}$ & No tengo problemas & Puedo controlarlo & $\begin{array}{l}\text { Puedo controlarlo pero } \\
\text { mis amigos me incitan } \\
\text { al uso }\end{array}$ & $\begin{array}{l}\text { Me siento mal cuando } \\
\text { pienso en el uso }\end{array}$ & $\begin{array}{l}\text { Necesito ayuda } \\
\text { (tratamiento) para } \\
\text { controlarme con el uso }\end{array}$ \\
\hline $\mid 11$ & $\begin{array}{l}\text { ¿Cómo te perciben los demás en } \\
\text { relación a tu uso con el teléfono } \\
\text { móvil? }\end{array}$ & $\begin{array}{l}\text { Lo normal para mi } \\
\text { edad }\end{array}$ & $\begin{array}{l}\text { Cuando lo uso } \\
\text { descuido las } \\
\text { responsabilidades con } \\
\text { mi familia }\end{array}$ & $\begin{array}{l}\text { Cuando lo uso } \\
\text { descuido las } \\
\text { responsabilidades con } \\
\text { mis amigos }\end{array}$ & $\begin{array}{l}\text { Mi familia o amigos me } \\
\text { aconsejan controlar o } \\
\text { reducir el uso }\end{array}$ & $\begin{array}{l}\text { Mi familia o amigos } \\
\text { ya han ido a buscar } \\
\text { ayuda (tratamiento) } \\
\text { por mi uso del teléfono } \\
\text { móvil }\end{array}$ \\
\hline
\end{tabular}

